\title{
Hospital Mortality in Acute Myocardial Infarction
}

\author{
R. M. NORRIS,* M.D., M.R.C.P., M.R.A.C.P. ; K. E. BENSLEY, † B.A.; D. E. CAUGHEY, $\ddagger$ M.B., M.R.C.P.ED., M.R.A.C.P. \\ P. J. SCOTT, $\S$ M.D., B.MED.SCI., M.R.C.P., F.R.A.C.P.
}

Brit. med. F., 1968, 3, 143-146

\begin{abstract}
Summary : All 757 patients with acute myocardial infarction admitted to the three public hospitals in Auckland during one year were studied. About 7\% died from cardiac arrhythmia four days or more after the onset of infarction. These patients had severe infarcts with circulatory failure on or shortly after admission to hospital. Late death from arrhythmia in patients recovering from circulatory failure may in many cases be preventable with anti-arrhythmic drugs.
\end{abstract}

\section{Introduction}

Previous mortality studies in acute myocardial infarction (Honey and Truelove, 1957 ; Beard et al., 1960 ; Killip, 1966) have shown that hospital mortality is greatest during the first day of admission and that 50 to $60 \%$ of deaths occur during the first three days and 60 to $70 \%$ during the first week after admission to hospital. Studies in which the time of death has been related to the mode of dying have shown a similar temporal distribution of arrhythmic deaths to total deaths (Ball et al., 1955), and a greater tendency for deaths from heart failure to occur late in the illness (Mower et al., 1964). The present prospective study was undertaken in conjunction with a previously reported trial of propranolol (Norris et al., 1968) in order to determine the natural pattern of hospital mortality and to define factors associated with prognosis.

Continuous electrocardiographic (E.C.G.) monitoring was not available in Auckland at the time of this study. Though this to some extent limited the amount of information available, it was thought that this disadvantage was outweighed by the opportunity of studying the natural history of death from infarction without the modifying factor of modern antiarrhythmic treatment (Lown et al., 1967). The patients reported here received no routine antiarrhythmic drugs apart from propranolol, which was shown to be ineffective in preventing sudden death. Information from this study has been applied to the management of patients in a coronary care unit which has been established at one hospital since the investigation was completed.

\section{Patients and Methods}

All 757 patients with myocardial infarction admitted to the three public hospitals in Auckland during one year were studied; 454 were included in the drug trial (Norris et al., 1968), while 303 were excluded, mainly because of conditions such as heart failure, shock, and bradycardia, which might have been exacerbated by the drug under test.

As in the drug trial, myocardial infarction was presumed to have occurred if two of the following three criteria were satisfied: (1) characteristic clinical presentation; (2) pathological $Q$ waves, $S T$ elevation, or $T$-wave inversion with evolutionary changes ; and (3) rise in serum aspartate aminotransferase (AsT) to over 40 units $/ \mathrm{ml}$. Necropsies were performed on $50 \%$ of

* Medical Specialist, Green Lane Hospital, Auckland, New Zealand. + Medical Statistician, Auckland Hospital Board.

\# Medical Specialist, Middlemore Hospital, Auckland.

\$ Physician and Research Fellow, Auckland Hospital. the patients who died, and the presence of a recent infarction was confirmed in all.

On admission to hospital patients had a chart completed on which personal details, previous ischaemic history, previous heart failure, other disease, time of onset of the most severe pain, and condition on admission, as judged by blood pressure, jugular venous pressure, and basal crepitations, were recorded in numerical form. In addition, heart size and lung fields were assessed by one radiologist from a chest $x$-ray film taken within 24 hours of admission, and serum AsT was measured daily for four days. Progress and complications were recorded thrice weekly until discharge, patients being treated according to conventional methods without E.C.G. monitoring or routine antiarrhythmic treatment apart from propranolol. All information was recorded in numerical form and was subsequently transferred to I.B.M. punch cards.

Death was recorded as being due to arrhythmia, cardiogenic shock, heart failure, cardiac rupture, pulmonary embolus, or other cause ; cardiac rupture and pulmonary embolus were in all cases verified at necropsy. For our purpose death was attributed to arrhythmia if it was sudden and unexpected; patients were either free of complications at the time of death or, if heart failure or shock was present, they were responding to treatment. In 33 of the 98 arrhythmic deaths (34\%) the terminal rhythm was identified during attempts at resuscitation, while a further seven patients who were successfully resuscitated from ventricular fibrillation were considered as cases of death from arrhythmia. Death from shock was defined as an irreversible lowering of blood pressure, while heart failure implied acute pulmonary oedema or congestive cardiac failure.

In all cases the time of death after the onset of the most severe chest pain or initial symptom, and after admission to hospital, was recorded separately on the punch cards. In an attempt to assess factors which influenced prognosis or which might determine the mode of dying, details of past history, admission status, and progress were compared in survivors, arrhythmia deaths, shock deaths, heart-failure deaths, and deaths from arrhythmia occurring more than three days after the onset of infarction. As a check on the findings, and in view of the possible uncertainty about the mode of death in patients who did not have E.C.G. monitoring, a further series of 211 patients monitored in a coronary care unit, which was opened after this study was completed (Norris, 1968), were studied to ascertain the temporal distribution of deaths from arrhythmia.

\section{Results}

Of the 757 patients 195 died-a total hospital mortality of $26 \%$. Seven were discharged from hospital after successful treatment of ventricular fibrillation, and are included in the analysis of deaths. The number and proportion of patients dying in the various ways are given in Table I, which shows that $52 \%$ of patients died of arrhythmia, $27 \%$ of shock, $14 \%$ of heart failure, and $7 \%$ of other causes. The time of death for all cases after admission to hospital, together with two other series (Killip, 1966 ; Honey and Truelove, 1957), is shown in the Chart, while the time of death after onset of the most 
TABLE I.-Mode of Dying of 195 Patients

\begin{tabular}{|c|c|c|c|c|c|c|}
\hline \multicolumn{5}{|c|}{ Mode of Dying } & \multirow[b]{2}{*}{$\begin{array}{l}\text { No. } \\
98+7^{*} \\
54 \\
29 \\
3 \\
3 \\
2 \\
6\end{array}$} & \multirow[b]{2}{*}{$\begin{array}{c}\% \\
52 \\
27 \\
14 \\
1 \cdot 5 \\
1 \cdot 5 \\
1 \\
3\end{array}$} \\
\hline $\begin{array}{l}\text { Arrhythmia } \\
\text { Shock } \\
\text { Heart failure } \\
\text { Arrhythmia cal } \\
\text { Cardiac ruptur } \\
\text { Pulmonary em } \\
\text { Other causes }\end{array}$ & $\begin{array}{l}\because . \\
\ddot{3} \\
\text { sing hea } \\
\text { bolus } \\
. .\end{array}$ & $\begin{array}{l}\because \\
\ddot{a r t} \text { failu } \\
\because \\
\therefore\end{array}$ & $\begin{array}{l}\ddot{ } \\
\ddot{0} \\
\ddot{0} \\
\cdots\end{array}$ & $\begin{array}{l}\because \\
\because \\
\because \\
\because \\
.\end{array}$ & & \\
\hline Total & .. & .. & .. & .. & 202 & 100 \\
\hline
\end{tabular}

* Hospital survivors from ventricular fibrillation.

severe pain or initial symptom in patients dying of arrhythmia, heart failure, or shock is given in Table II.

TABle II-Time of Death Related to Mode of Dying

\begin{tabular}{|c|c|c|c|c|c|c|c|c|c|}
\hline \multirow{2}{*}{\multicolumn{2}{|c|}{ Mode of Dying }} & \multicolumn{8}{|c|}{$\begin{array}{c}\text { Tims of Death in Days After Onset of Pain or } \\
\text { Initial Symptom }\end{array}$} \\
\hline & & $0-1$ & 2 & 3 & $4-7$ & $8-14$ & $15-21$ & $22+$ & Total \\
\hline $\begin{array}{l}\text { Arrhythmia } \ldots \\
\text { Shock } \\
\text { Heart failure .. } \\
\text { All other causes }\end{array}$ & $\ddot{0}$ & $\begin{array}{r}23 \\
33 \\
5 \\
1\end{array}$ & $\begin{array}{l}6 \\
3 \\
2 \\
2\end{array}$ & $\begin{array}{l}6 \\
2 \\
0 \\
2\end{array}$ & $\begin{array}{r}21 \\
4 \\
3 \\
0\end{array}$ & $\begin{array}{r}30 \\
8 \\
8 \\
2\end{array}$ & $\begin{array}{l}9 \\
0 \\
5 \\
2 \\
\end{array}$ & $\begin{array}{r}10 \\
4 \\
6 \\
5 \\
\end{array}$ & $\begin{array}{r}105 \\
54 \\
29 \\
14 \\
\end{array}$ \\
\hline Total & 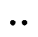 & 62 & 13 & 10 & 28 & 48 & 16 & 25 & 202 \\
\hline
\end{tabular}

It is seen from Table II that the distribution of deaths from arrhythmia and heart failure is different from that of shock, there being a greater number of deaths from arrhythmia and heart failure from the fourth day onwards after the onset of infarction. Of these dying of arrhythmia $70(67 \%)$ died from the fourth day onwards (late arrhythmic deaths), while 16 (30\%) shock deaths and $22(76 \%)$ heart-failure deaths occurred four days or more after onset of the pain. Further analysis of the arrhythmia deaths, however, showed that the proportion of early to late arrhythmia deaths was very dependent on the

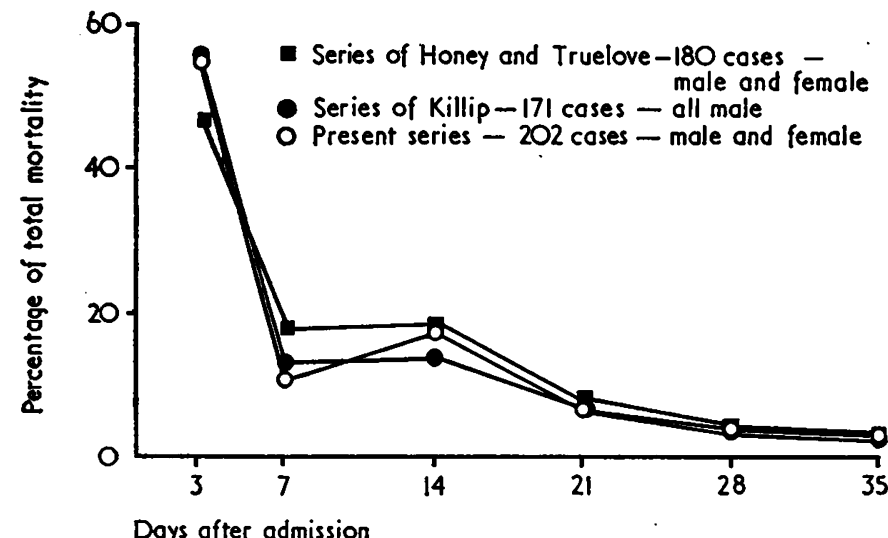

Percentage of total hospital deaths from acute myocardial infarction according to the day after admission to hospital in the present and two previously reported series.

time of admission to hospital, patients admitted within six hours of onset of the most severe chest pain being more liable to early death (Table III). The proportion of patients dying from arrhythmia four days or more after infarction was the

TABLE III.-Time of Occurrence of Arrhythmic Death Related to Time of Admission to Hospital

\begin{tabular}{|c|c|c|c|c|c|c|c|}
\hline \multirow{3}{*}{\multicolumn{3}{|c|}{$\begin{array}{l}\text { Time of Admission } \\
\text { After Onset of Pain }\end{array}$}} & \multirow{3}{*}{$\begin{array}{l}\text { No. of } \\
\text { Patients }\end{array}$} & \multicolumn{4}{|c|}{ Time of Death Arter Onset of Pain } \\
\hline & & & & \multicolumn{2}{|c|}{ 0-3 Days } & \multicolumn{2}{|c|}{4 Days or More } \\
\hline & & & & No. & $\begin{array}{c}\% \text { of } \\
\text { Patients }\end{array}$ & No. & $\begin{array}{c}\% \text { of } \\
\text { Patients }\end{array}$ \\
\hline $\begin{array}{l}\text { 0-6 hours } \\
6-24 \text { ho::ss } \\
1-7 \text { days }\end{array}$ & $\ddot{0}$ & $\ddot{0}$ & $\begin{array}{l}262 \\
239 \\
174\end{array}$ & $\begin{array}{r}23 \\
5 \\
3\end{array}$ & $\begin{array}{l}9 \\
2 \\
2\end{array}$ & $\begin{array}{l}19 \\
17 \\
23\end{array}$ & $\begin{array}{r}7 \\
7 \\
13\end{array}$ \\
\hline Total & .. & .. & $675^{*}$ & 31 & 5 & 59 & 9 \\
\hline
\end{tabular}

- Bighty-two patients, including 15 arrhythmic deaths, are excluded because of uncertainty over the precise time of onset of infarction, or admission after one week. same in all those admitted within 24 hours of the onset (7\%), the incidence of late arrhythmic death rising to $13 \%$ in patients admitted from one to seven days after the onset.

Twenty-six of the 211 patients who have since been monitored in a coronary care unit in one of the three hospitals involved in this survey died suddenly from arrhythmia or were resuscitated from ventricular fibrillation, and in 14 of these the arrhythmia occurred four days or more after the onset of chest pain. In all but one case the patient was being monitored or was under observation at the moment of death. This confirms an incidence of late arrhythmic death of approximately $7 \%$.

Possible factors associated with death in hospital are given according to the mode of dying in Tables IV to VII. Though the average age of patients who died (67.4 years) was significantly greater than that of the survivors $(60.5$ years ; $P<0.01)$, there was no difference in age in the three modes of dying (shock death 68.9 years, heart failure 68.7 years, arrhythmia 66.5 years, late arrhythmia 65.3 years). When sex is considered (Table V) it is seen that in women $43 \%$ of shock deaths occurred, compared with $24 \%$ of heart-failure deaths, $28 \%$ of arrhythmic deaths, and $27 \%$ of late arrhythmic deaths; this increased incidence of death from shock was of borderline significance $(P<0.10)$.

\begin{tabular}{|c|c|c|c|c|c|c|}
\hline $\begin{array}{l}\text { Survivors } \\
\text { All deaths } \\
\text { Shock deaths }\end{array}$ & $\ddot{0}$ & $\ddot{\ddot{*}}$ & $\begin{array}{l}60.5 \text { years } \\
67.4 \% \\
68.9 \%\end{array}$ & $\begin{array}{l}\text { Heart-failure deaths } \\
\text { Arrhythmia deaths } \\
\text { Late arrhythmia.. }\end{array}$ & $\because$ & $\begin{array}{l}68 \cdot 7 \text { year: } \\
66 \cdot 5 \text { " } \\
65 \cdot 3 \%\end{array}$ \\
\hline
\end{tabular}

TART F V.-Protortion of Males to Females

\begin{tabular}{|c|c|c|c|c|c|c|}
\hline & & Males & Females & & Males & Females \\
\hline $\begin{array}{l}\text { Survivors .. } \\
\text { All deaths .: } \\
\text { Shock deaths }\end{array}$ & $\because$ & $\begin{array}{l}69 \% \\
67 \% \\
57 \%\end{array}$ & $\begin{array}{l}31 \% \\
33 \% \\
43 \%\end{array}$ & $\begin{array}{l}\text { Heart failure deaths } \\
\text { Arrhythmia deaths } \\
\text { Late arrhythmia .. }\end{array}$ & $\begin{array}{l}76 \% \\
72 \% \\
73 \%\end{array}$ & $\begin{array}{l}24 \% \\
28 \% \\
27 \%\end{array}$ \\
\hline
\end{tabular}

TABLE VI.-Factors in Past Medical History Associated with Hospital Mortality

\begin{tabular}{|c|c|c|c|c|c|c|}
\hline Factor & $\begin{array}{l}\text { Sur- } \\
\text { vivors } \\
\text { (555) }\end{array}$ & $\underset{\text { Deaths }}{\text { All }}$ & $\begin{array}{c}\text { Shock } \\
\text { Deaths } \\
\text { (54) }\end{array}$ & $\begin{array}{c}\text { Failure } \\
\text { Deaths } \\
\text { (29) }\end{array}$ & $\begin{array}{l}\text { Arrhyth } \\
\text { mic } \\
\text { Deaths } \\
\text { (105) }\end{array}$ & $\begin{array}{c}\text { Late } \\
\text { Arrhyth } \\
\text { mic } \\
\text { Deaths } \\
\text { (70) }\end{array}$ \\
\hline \multicolumn{7}{|c|}{ Percentage of Patients Having the Factor } \\
\hline \multirow{6}{*}{$\begin{array}{l}\text { Angina of } 3 \text { months' } \\
\text { duration; no infaret } \\
\text { One previous infarct .. } \\
\text { More than one previous } \\
\text { infaret } \\
\text { Previous ischaemia (total } \\
\text { of above) .. } \\
\text { Dyspnoea not associated } \\
\text { with lung disease ... } \\
\text { Heart failure necessitat- } \\
\text { ing treatment in bed } \\
\text { Diabetes } \\
\text { Hypertension .. }\end{array}$} & & & & & & \\
\hline & $\begin{array}{l}23 \\
23\end{array}$ & $\begin{array}{l}31^{*} \\
22\end{array}$ & $\begin{array}{l}28 \\
19\end{array}$ & $\begin{array}{l}35 \\
24\end{array}$ & $\begin{array}{l}32 \\
25\end{array}$ & $\begin{array}{l}23 \\
26\end{array}$ \\
\hline & 6 & 7 & 11 & 7 & 5 & 5 \\
\hline & 52 & $61 *$ & 58 & 66 & 62 & 54 \\
\hline & 23 & $31 *$ & 24 & 31 & 33 & 31 \\
\hline & $\begin{array}{r}5 \\
10 \\
19\end{array}$ & $\begin{array}{l}11 * \\
10 \\
19\end{array}$ & $\begin{array}{l}7 \\
6 \\
7 * t\end{array}$ & $\begin{array}{l}24 * \\
17 \\
14\end{array}$ & $\begin{array}{r}8 \\
11 \\
27\end{array}$ & $\begin{array}{r}11 \\
9 \\
26\end{array}$ \\
\hline
\end{tabular}

- Incidence significantly different from survivors $(P<0.02)$.
+ Incidence significantly different from total deaths $(P<0.02)$.

Table VI shows factors in the past history, with their occurrence in all patients and in patients who died of shock, heart failure, arrhythmia, or late arrhythmia. Surprisingly, neither a history of hypertension nor of diabetes was associated more commonly with death than survival. A past history of ischaemic heart disease was associated more often with death $(61 \%)$ than with survival $(52 \%)$, though in the three groups of angina without infarction, one previous infarct, or more than one previous infarct the increased likelihood of death was significantly greater only in angina (present in $31 \%$ of deaths and $23 \%$ of survivors). No factor was of statistical significance in predicting the mode of dying except that previous hypertension seemed to protect against death from shock. Only $7 \%$ of shock deaths compared with $19 \%$ of all patients dying had a history of hypertension.

Admission status (Table VI) was of much greater value than past history in predicting survival. Right or left heart failure as evidenced on admission by a raised jugular venous pressure 
or basal crepitations, a systolic blood pressure below $110 \mathrm{~mm}$. $\mathrm{Hg}$, full-thickness infarction, and the $x$-ray appearance of interstitial or pulmonary oedema were all associated with a significantly greater total mortality. However, none of these complications had any predictive value in determining the mode of dying, except that moderate or marked basal crepitations were more often associated with death from heart failure, and a systolic B.P. of less than $110 \mathrm{~mm}$. $\mathbf{~ H g}$ with death from shock.

TABLE VII.-Factors in Initial Clinical Examination Associated with Hospital Mortality

\begin{tabular}{|c|c|c|c|c|c|c|}
\hline Factor & $\begin{array}{l}\text { Sur- } \\
\text { vivors } \\
(555)\end{array}$ & $\begin{array}{c}\text { All } \\
\text { Deaths } \\
\text { (202) }\end{array}$ & $\begin{array}{l}\text { Shock } \\
\text { Deaths } \\
\text { (54) }\end{array}$ & $\begin{array}{c}\text { Failure } \\
\text { Deaths } \\
\text { (29) }\end{array}$ & $\begin{array}{l}\text { Arrhyth- } \\
\text { mic } \\
\text { Deaths } \\
\text { (105) }\end{array}$ & $\begin{array}{c}\text { Late } \\
\text { Arrhyth- } \\
\text { mic } \\
\text { Deaths } \\
(70)\end{array}$ \\
\hline
\end{tabular}

\begin{tabular}{|c|c|c|c|c|c|c|}
\hline \multirow{2}{*}{\multicolumn{7}{|c|}{ Percentage of Patients Having the Factor }} \\
\hline & & & & & & \\
\hline pressure & $\begin{array}{l}23 \\
43\end{array}$ & $\begin{array}{l}48 * \\
66^{*}\end{array}$ & $\begin{array}{l}43 * \\
59 *\end{array}$ & $\begin{array}{l}59 * \\
76^{*}\end{array}$ & $\begin{array}{l}48 * \\
68 *\end{array}$ & $\begin{array}{l}52 * \\
74^{*}\end{array}$ \\
\hline erate or marked & 22 & $49 *$ & $46^{*}$ & $69 * t$ & $45^{*}$ & $48^{*}$ \\
\hline mm. Hg infarction & $\begin{array}{l}10 \\
56\end{array}$ & $\begin{array}{l}37 * \\
72 *\end{array}$ & $67 * t$ & $\begin{array}{l}28 * \\
69\end{array}$ & $\begin{array}{l}28 * \\
72 *\end{array}$ & $\begin{array}{l}22^{*} \\
68^{*}\end{array}$ \\
\hline $\begin{array}{l}\text { Antercor transmural in- } \\
\text { farction } \text {-ray evidence of inter- }\end{array}$ & 28 & $44^{*}$ & 35 & 38 & $48^{*}$ & $43^{*}$ \\
\hline oedema pulu & 20 & $54 *$ & $52 *$ & $66^{*}$ & $51 *$ & $53^{\circ}$ \\
\hline
\end{tabular}

Incidence significantly different from survivors $(P<0.02)$.
+ Incidence significantly different from total deaths $(<0.02)$.

\section{Discussion}

Numerous retrospective studies have been made of hospital montality in myocardial infarction (Rosenbaum and Levine, 1941 ; Mintz and Katz, 1947 ; Billings et al., 1949 ; Doscher and Poindexter, 1950 ; Honey and Truelove, 1957 ; Killip, 1966), and the wide range of mortality between approximately 15 and $40 \%$ is almost certainly due to selection of cases rather than to differences in standard of treatment. Nevertheless, there is general agreement on the temporal distribution of deaths (see Chart). There is, however, no prospective study describing the pattern of death according to the mode of dying defined by prearranged criteria, previous reports being concerned with groups of cases studied retrospectively from the case notes (Ball et al., 1955 ; Mower et al., 1964 ; Grendahl, 1967).

Ball et al. (1955) found a similar distribution of arrhythmic deaths to total deaths in a group of 342 patients, with a $26 \%$ mortality one month after infarction. Of these deaths $23 \%$ occurred on the first day, $50 \%$ during the rest of the first week, and $27 \%$ during the rest of the first month. Ventricular fibrillation was presumed to be the cause of death in $65 \%$ of cases ; $29 \%$ of these occurred on the first day, $42 \%$ during the rest of the first week, and $29 \%$ during the rest of the first month. Mower et al. (1964), however, found that deaths from heart failure were more likely to occur late in the illness (mean (10.4 days after onset) than deaths from hypotension (mean 5.3 days) or arrhythmia (5.0 days). Grendahl (1967) does not comment in detail on the temporal distribution of deaths according to the mode of dying, but analysis of the figures given indicates that $50 \%$ of acute arrhythmia deaths occurred more than.three days after admission to hospital compared with $30 \%$ of deaths from all other causes. The relevance of this to the present study is uncentain, however, as only $26 \%$ of the deaths described by Grendahl were considered to be due to acute arrhythmia.

A possible objection to the present definition of arrhythmic death is that the patients did not have E.C.G. monitoring, were often not under observation at the moment of death, and in two-thirds of cases the terminal rhythm was not identified. Sudden death after myocardial infarction may be due to cardiac rupture or pulmonary embolus, cardiac rupture being found at necropsy in $4.7 \%$ of patients with infarction (London and London, 1965), while pulmonary embolus occurs in $28 \%$ of necropsies, but probably is the cause of death in only $4 \%$ of cases, this figure being reduced to $1.4 \%$ by anticoagulant treatment (Hilden et al., 1961). As necropsy was performed in only half the patients who died in this series, and as cardiac rupture and pulmonary embolus were not diagnosed without necropsy, it is probable that a further five patients died from these causes in addition to the five recorded in Table I as having done so. Death from heart failure and shock may also occur rapidly, but in our experience it is rare for this to occur in less than about 30 minutes. With relatively close nursing observation, usually in open wards, it is thought to be unlikely that more than a small proportion of deaths in the present series attributed to arrhythmia were actually due to cardiac failure or shock. In addition, the total proportion of arrhythmic deaths $(52 \%)$ is not greater than that reported from the other series (Mower et al., 1964), while a similar experience with late arrhythmias in patients subsequently monitored in a coronary care unit is also in agreement. For these reasons it is concluded that the diagnosis of arrhythmia as a mode of dying was correct in all but a few cases, and these would not alter the general conclusions drawn from this survey.

It is evident that the relatively low mortality from arrhythmia during the first three days in this study is a reflection of late admission to hospital. The findings in community studies (Bainton and Peterson, 1963 ; Pell and D'Alonzo, 1964) that approximately $85 \%$ of deaths from infarction occur within the first 24 hours, together with those of Pemberton and McNeilly (1967) that of 901 fatal coronary attacks in Belfast during a one-year period only 414 patients reached hospital, while 102 were dead on arrival, suggest that the present report may deal with only 20 to $35 \%$ of coronary deaths in our community. This rests on the assumption that the Auckland community does not differ significantly from the communities in the previous reports. The provision of a mobile intensive care unit in Belfast now ensures that two-thirds of admitted patients come under intensive care within four hours of onset, with a consequent $9 \%$ incidence of ventricular fibrillation in patients seen within four hours (Pantridge and Geddes, 1967). This is comparable with our own incidence of $9 \%$ of arrhythmic deaths in patients admitted within six hours, and emphasizes that the present results are not in conflict with those of other workers. Nevertheless, the $7 \%$ mortality from late arrhythmia found in patients admitted up to six hours or six to 24 hours after the onset suggests that the proportion of late arrhythmic deaths is not influenced by the time of hospital admission up to 24 hours after infarction. The $13 \%$ mortality from late arrhythmia in patients admitted between one and seven days after infarction is probably due to selection of more seriously ill patients.

The information in Tables VI and VII is an attempt to identify factors which may be of importance in predicting the likelihood and mode of dying. The main facts that emerge are that the past history is a poor guide to prognosis, but that the patient's condition on admission is of great importance. Though the negative prognostic value of the past history, particularly with regard to previous myocardial infarction, is surprising, the same observation was made by Honey and Truelove (1957) ; a possible explanation is that patients with second or third infarcts are more likely to die before reaching hospital (Bainton and Peterson, 1963). Most reports agree that there is no adverse effect of hypertension on early survival (Billings et al., 1949 ; Honey and Truelove, 1957 ; Beard et al., 1960), though earlier workers have found an adverse effect of diabetes (Billings et al., 1949 ; Honey and Truelove, 1957). Inaccurate reporting and varying criteria for diagnosis are obvious factors limiting the reliability of historical information. In the present study the information gained in accuracy by being obtained prospectively, but it was not possible to enforce strict criteria for the diagnosis of previous infarction, hypertension, or diabetes.

Though the condition on admission gave useful prognostic information, it was still a poor guide to the likely mode of 
dying, heart failure on admission, as determined clinically and radiologically, being nearly as likely to result in death from arrhythmia as in death from failure. Patients suffering late arrhythmic death were, however, much more ill than the survivors, having a greatly increased incidence of shock and heart failure, and a greater incidence of transmural infarction, particularly involving the anterior part of the heart. A detailed analysis of our 70 cases of late arrhythmic death showed that, excluding a few who had clearly diagnosable reinfarction, all but four had radiological evidence of interstitial or pulmonary oedema on admission, or heart failure, hypotension, or a major arrhythmia during the first few days after admission.

It is doubtful whether long-term E.C.G. monitoring of all patients at risk of late arrhythmic death is economically feasible or psychologically desirable, and it is probable that the yield in lives saved will be considerably less than by the institution of early intensive care as practised by Pantridge and his colleagues. It is also true that ventricular fibrillation complicating heart failure or shock has a poor prognosis in spite of monitoring and resuscitation (Robinson, 1965). Nevertheless, it is thought that arrhythmic death in patients who are recovering from circulatory failure is in many cases preventable with antiarrhythmic drugs, and the logical use of E.C.G. telemetry (Cerkez et al., 1965) is in this group of patients.

It is now our practice, in a four-bedded coronary care unit which has opened at Green Lane Hospital since this study was completed, to readmit patients who have had heart failure or major arrhythmia during their three to seven days of initial monitoring from the ward to the unit if their condition deteriorates. Warning signs of impending death from ventricular fibrillation are taken to be further chest pain not quickly relieved by trinitrin, a fall in blood pressure, or irregularity in the pulse which was not present before. Nurses are instructed to feel the pulse at the wrist of all coronary patients for a full minute and to report irregularities and ectopic beats. As late arrhythmic death occurs so seldom in uncomplicated cases, it can be argued that it is unnecessary to keep these patients in hospital for more than a week, and that mobilization and rehabilitation may be correspondingly accelerated.

We are grateful to the visiting physicians of Auckland, Green Lane, and Middlemore Hospitals for allowing patients under their care to be studied, and to the medical registrars for accurate recording of information. Dr. P. W. T. Brandt, radiologist to the cardiological and cardiothoracic surgical units at Green Lane Hospital, kindly reviewed all the chest $x$-ray films. Facilities for the transfer of data to punch cards and analysis of the results were provided by the medical statistics unit of the Auckland Hospital Board.

\section{REFERENCES}

Bainton, C. R., and Peterson, D. R. (1963). New Engl. F. Med., 268, 569.

Ball, C. O. T., Billings, F. T., jun., Furman, R. H., Brothers, G. B., Thomas, J., and Meneely, G. R. (1955). Circulation, 11, 749.

Beard, O. W., Hipp, H. R., Robins, M., Taylor, J. S., Ebert, R. V., and Beran, L. G. (1960). Amer. F. Med., 28, 871.

Billings, F. T., jun., Kalstone, B. M., Spencer, J. L., Ball, C. O. T., and Meneely, G. R. (1949). Amer. Ұ. Med., 7, 356.

Cerkez, C. T., Steward, G. C., and Manning, G. W. (1965). Canad. med. Ass. F., 93,1187

Doscher, N., and Poindexter, C. A. (1950). Amer. F. Med., 8, 623.

Grendahl, H. (1967). Acta med. scand., 181, 655.

Hilden, T., Iversen, K., Raaschou, F., and Schwartz, M. (1961). Lancet, 2. 327 .

Honey, G. E., and Truelove, S. C. (1957). Lancet, 1, 1155.

Killip, T. (1966). In The Current Status of Intensive Coronary Care. American College of Cardiology, New York.

London, R. E., and London, S. B. (1965). Circulation, 31, 202.

Lown, B., Fakhro, A. M., Hood, W. B., jun., and Thorn, G. W. (1967) 7. Amer. med. Ass., $199,188$.

Mintz, S. S., and Katz, L. N. (1947). Arch. intern. Med., 80, 205.

Mower, M. M., Miller, D. I., and Nachlas, M. M. (1964). Amer. Heart 7., 67, 437.

Norris, R. M. (1968). N.Z. med. F., 67, 470.

Norris, R. M., Caughey, D. E., and Scott, P. J. (1968). Brit. med. F., 2, 398.

Pantridge, J. F.; and Geddes, J. S. (1967). Lancet, 2, 271.

Pemberton, J., and McNeilly, R. H. (1967). Quoted by Pantridge and Geddes (1967).

Robinson, J. S. (1965). Amer. Hearı f., 69, 285.

Rosenbaum, F. F., and Levine, S. A.' (1941). Arch. intern. Med., 68, 913.

\title{
Organochlorine Pesticide Residues in Human Fat in Great Britain
}

\author{
D. C. ABBOTT,* B.SC., PH.D., F.R.I.C. ; R. GOULDING, † M.D., B.SC., M.R.C.P. ; J. O’G. TATTON,* M.SC., F.R.I.C.
}

\begin{abstract}
Cummary : In order to assess the trend in the body load $S$ of organochlorine pesticide residues in Great Britain, between July 1965 and June 1967 samples of fat were taken during routine necropsies on 247 subjects over 3 years old and on 44 stillborn or premature babies and infants below the age of 3 . The levels of the three main pesticides, B.H.C., dieldrin, and D.D.T., were lower than those found in an earlier survey carried out in 1963 and 1964. No marked differences were observed in levels throughout Britain, but the levels in man were higher than those in women. Britain compares favourably with other countries in which similar surveys have been done.
\end{abstract}

\section{Introduction}

The presence of organochlorine pesticide residues in human body tissues continues to attract considerable attention. Originally a matter of curiosity and concern, the determination of national mean concentration levels of these pesticides in

* Laboratory of the Government Chemist, London S.E.1.

+ Principal Medical Officer (Toxicology), Ministry of Health, London. human fat has now come to be regarded more as a method of measuring the degree of exposure to which a population is subjected. Useful information can be derived from each set of results and also from any trends that may become apparent from year to year. The effects of the general withdrawal from use of certain pesticides, or the introduction of new compounds into agricultural and veterinary practice, can be followed by such studies.

Between 1965 and 1967 at least 15 publications have appeared giving results of analyses of samples of human fat from such widespread sources as, for example, India (Dale et al., 1965), Israel (Wassermann et al., 1965), Denmark (Wiehe, 1966), New Zealand (Brewerton and McGrath, 1967), and New Orleans (Hayes et al., 1965). All of these papers tell much the same story; that these organochlorine pesticide residues are omnipresent. The papers differ, however, in reporting mean concentration levels, varying sometimes by orders of magnitude according to country.

In Britain an early study in 1961 was confined to Southeast England (Hunter et al., 1963). In 1963 and 1964 a further study, instigated by the Advisory Committee on Pesticides and Other Toxic Chemicals, was carried out jointly by 